\title{
The Effectiveness of Kahoot! in Improving Understanding of Scientific Works in the Distance Learning
}

\author{
Alimatussa'diyah ${ }^{1)}$ Candra Oktyasari Putri $^{2)}$, Okpina Rochadian ${ }^{3)}$, Pangkat Mondiana $\mathbf{S}^{4)}$ \\ Ericka Ratna $\mathbf{N}^{5}$ \\ ${ }^{1,2,3,4,5)}$ Politeknik Maritim Negeri Indonesia \\ *Coresponding Author \\ Email : alimatussadiya@polimarin.ac.id
}

\begin{abstract}
The Covid-19 virus pandemic that has hit the world since two years ago has changed the education system rapidly and extremely, mainly in the process of teaching and learning activities. All learning activities turn into distance learning. This research tries to study the students of Semarang Polymarine in the Commercial and Port Shipping Management Study Program who take an Indonesian language course. It has two main objectives. The first is to improve the students' ability to write scientific papers on distance learning. The second one is to find out the effectiveness of using Kahoot! to improve the ability to write scientific papers on distance learning. This is a classroom action research that consists of two cycles each research stage to identify and view the implementation of the Kahoot! in the learning process. Each cycle is divided into four stages of research. They are planning, implementation, observation, and reflection. This research uses three techniques in data collection, namely observation, interviews, and documentation. The results show that there is an increase in the students' learning outcomes which can be seen from the post-test scores. The use of Kahoot! can also be said as successful, because the students' learning outcomes have reached $75 \%$ of the students' being tested
\end{abstract}

\section{Keywords: Distance Learning, Kahoot!, write scientific papers}

\section{INTRODUCTION}

The Covid-19 pandemic has started at the beginning of 2020. The world is experiencing all kinds of extreme and rapid changes in dealing with the pandemic. The educational world of course also experiences major transformations in the process of teaching and learning activities. Circular number 4 of 2020 from the Minister of Education and Culture recommends that all educational institutions are required to maintain distance learning and all learning activities must be done at each student's home so that all learning methods become distance learning.

As a relatively new method, distance learning cannot be separated from various obstacles. One of them is that the students are getting more difficult to understand the materials given. Meanwhile, writing scientific papers is one of the topics that will be much easier to understand if it is delivered directly using the face-to-face method. Therefore, it is necessary to be innovative in the learning process to facilitate the students' understanding of scientific works. Ahmad et al (2020) stated that one way to make it easier for students to understand the material is to make discoveries and adaptations related to the use of available technology to support the learning process. The progress of the times of course also requires technological tools.

The distance learning that is carried out monotonously also contributes to a lesseffective learning process. It is important to use appropriate technology to overcome monotony and boredom during distance learning. Gunawat et al (2020) stated that distance learning can take advantage of platforms such as software, websites, social networks, and learning management systems. 
Based on some descriptions above, it is assumed that the technology can help to solve the problems presented. The technology in question is called Kahoot. Kahoot is intended to support innovative learning activities. Therefore, it is expected that students' learning outcomes can increase significantly after learning using this medium.

Several previous studies are relevant to this research such as Zarycka-Pirzkorz's (2016) study entitled "Kahoot It or Not? Can Games Be Motivating In Learning Grammar? Teaching English with Technology". This study found that Kahoot has a positive effect on learning English. It is also very useful for English language teachers because it provides more practical things in their teaching process.

Another is Zeynap Turan and Elif Meral (2017) who conducted research entitled "Game-Based Versus to Non-Game-Based: The Impact of Student Response Systems on Students "Achievements, Engagements and Test Anxieties". They found that the students who used Kahoot had higher academic achievement and engagement levels with lower test anxiety.

Leung E et al (2018) conducted research entitled "Effectiveness of Gamification Activities in a Project-based Learning Classroom. Paper presented at ASEE Annual Conference \& Exposition". They examined the learning efficacy using the Kahoot quiz game to improve student's learning outcomes and engagement in the learning. This Kahoot is useful for educators to evaluate the students' learning outcomes using media in the classroom.

Felszeghy et al (2019) conducted research entitled "Using Online Game-Based Platforms To Improve Student Performance And Engagement In Histology Teaching". In BMC Medical Education". This study examines the effects of applying Kahoot at a dental school at a university in Finland. This research showed that Kahoot successfully increased motivation in learning and enabled the students to overcome their difficulties.

Internet-based interactive media Kahoot has four main features, namely games, quizzes, discussions, and general news. Games and quizzes can be played in groups or individually. In the answering process, images and colors will be used to provide the correct answer. The Kahoot game requires users to answer correctly, quickly, and carefully the displayed questions. There are two ways to access Kahoot, namely becoming an admin and becoming a participant. By becoming an admin, the Kahoot can be accessed through the web address http://getKahoot.com/ while the participants can go through the web address https://create.Kahoot.it/

Some specific problems have motivated the researcher to conduct a research entitled "Improving Scientific Writing Ability in KPN Study Program Students using Kahoot! in Distance Learning". This research aims to improve the students' ability in writing bibliography on scientific papers. The Kahoot! software is designed to make it easier for the students to learn about everything. Using the software, the students can practically understand how to write a scientific work and implement the materials delivered well.

The learning using Kahoot! can also be included as a discovery learning so that the process can be more interesting and run smoothly, both for remote and face-to-face learning methods.

\section{RESEARCH METHODS}

This is a Classroom Action Research. An opinion that underlies the Classroom Action Research was expressed by Ani Widayati (2008) in her journal entitled "Classroom Action Research" She stated that Classroom Action Research is research carried out to solve learning problems faced by teachers, improve the quality and learning outcomes, and apply new things in learning for the sake of improving the quality and learning outcomes. Didik Komaidi, et al (2011:3) stated that the Classroom Action Research is an observation of learning activities in 
the form of an action, which is deliberately raised and occurs in a class together.

The Classroom Action Research requires minimally two cycles that will be carried out with the same stages. First, it begins with a plan. In this stage, the researcher plans actions about what, why, when, where, by whom, and how the action is carried out. The second one is action. In this stage, the researcher takes actions that have been well-planned previously. The third one is observation, where the researcher observes the subject being studied, records what is needed and everything that may happen when the action is taken. The fourth step is reflection. In this stage, the researcher thoroughly examines the actions that have been taken and check what mistakes have occurred in cycle I. The next stage is cycle II where the stages run like a cycle I, but with some improvements. The researcher uses the Kemmis \& McTaggart cycle model (Arikunto, 2010:137).

\section{RESULTS AND DISCUSSION}

The results show Kahoot media can improve the students' learning outcomes significantly. This improvement can be seen in the comparison of the average post-test scores in each cycle. The student's learning outcomes can be seen in the following table.

Table 1 Comparison of the Average Scores of the Students' Learning Outcomes in Cycles I and II

\begin{tabular}{|c|c|c|c|}
\hline \multirow{2}{*}{ Criteria } & \multicolumn{2}{|c|}{ Score } & \multirow{2}{*}{ Improvement } \\
\cline { 2 - 3 } & $\begin{array}{c}\text { Average Pre-test } \\
\text { Score }\end{array}$ & $\begin{array}{c}\text { Average Post-test } \\
\text { Score }\end{array}$ & \\
\hline Cycle I & 45,4 & 81,2 & 35,8 \\
\hline Cycle II & 48,6 & 85,7 & 37,1 \\
\hline
\end{tabular}

Source: Processed Primary Data

The table for the percentage of completeness in each cycle is shown as follows.

Table 2 Comparison of the Percentage of Completeness of the Students' Learning Outcomes in Cycles I and II

\begin{tabular}{|c|c|c|c|}
\hline \multirow{2}{*}{ Criteria } & \multicolumn{2}{|c|}{ Cycle } & \multirow{2}{*}{ Improvement } \\
\cline { 2 - 3 } & I & II & \\
\hline Pre-test Score $\geq 75$ & $7,69 \%$ & $14,29 \%$ & $6,59 \%$ \\
\hline Post-test Score $\geq 75$ & $61,54 \%$ & $90,48 \%$ & $28,94 \%$ \\
\hline Improvement & $53,85 \%$ & $76,19 \%$ & $22,34 \%$ \\
\hline
\end{tabular}

Based on the table of the students' learning outcomes in cycle I and cycle II, it can be seen that the pre-test and post-test scores have increased significantly. The average score of the Pre-test in the first cycle is 45.4, and the average post-test is 81.2 (there is an increase of 35.8). Meanwhile, the average score of the pre-test in the second cycle is 48.6 , and the average posttest score is 85.7 (there is an increase of 37.1). The percentage of students' pre-test completeness in the first cycle is $7.69 \%$ or 2 out of 26 students have had achieved the minimum score required, while in the second cycle it is $15.38 \%$ which means 4 out of 26 students have had achieved the minimum score required. The post-test result in the first cycle is $61.54 \%$, or 16 of 26 students have achieved the minimum score required, while in the second cycle, there is $88.46 \%$ or 23 of 26 students who have achieved the minimum score required. 
The success of the research can be seen from the post-test results. The average score of the post-test in the first cycle is 81.2 , while the average score of the post-test in the second cycle is 85.7. Therefore, there is an increase of 4.5. Another indicator of success is that at least $75 \%$ of students in one class have obtained the minimum score (KKM) that has been set, namely 75 . In the second cycle, the results of the post-test show that 23 out of 26 students $(88.48 \%)$ have reached the KKM (75). This means that the use of Kahoot can improve the students' learning outcomes

\section{CONCLUSION}

Based on the research findings and discussion, it can be concluded that Kahoot media is proven to be effective in improving learning outcomes. The effectiveness is evidenced by an increase in the percentage of the average score and the percentage of completeness. The classroom action research can be carried out optimally using more varied learning methods and can be combined with other internet-based media to improve the quality of learning activities

\section{REFERENCES}

Ahmed, S., Shehata, M., \& Hassanien, M. (2020). Emerging Faculty Needs for Enhancing Student Engagement on a Virtual Platform. MedEdPublish, 1-5. https://doi.org/https://doi.org/10.15694/mep .2020.000075.1

Christiani, Natalia, Dr. M.Pd. Adrianto, Hebert., S.Si., M.Ked Trop. Anggraini, Lya Dewi, S.T., M.T., Ph. D. 2019. Modul Teknologi Pembelajaran KAHOOT. CV Jejak, anggota IKAPI. Sukabumi. Jawa Barat.

Direktorat Jenderal Pendidikan Tinggi Kemdikbud RI . 2020. Buku Panduan Penyelenggaraan Pembelajaran Semester Gasal 2020/2021 di Perguruan Tinggi. Jakarta: Direktorat Jenderal Pendidikan Tinggi Kemdikbud RI.

Felszeghy, S., et al. (2019). Using Online Game-Based Platforms to Improve Student Performance and Engagement in Histology Teaching. In BMC Medical Education.

Gunawan, Suranti, N. M. Y., \& Fathoroni. (2020). Variations of Models and Learning Platforms for Prospective Teachers During the COVID-19 Pandemic Period. Indonesian Journal of Teacher Education, 1(2), 61-70.

Leung, E., \& Pluskwik, E. (2018). Effectiveness of Gamification Activities in a Project-based Learning Classroom. Paper presented at ASEE Annual Conference \& Exposition.

Official Website „Kahoot!”. (2017). kahoot.com/company/. Retrieved from https://kahoot.com/company/

Suharsimi, Arikunto dkk. 2007. Penelitian Tindakan. Jakarta: Bumi Aksara.

Suwarsih, Madya. 1994. Panduan Penelitian Tindakan. Yogyakarta :Lembaga Penelitian IKIP Yogyakarta. 